\title{
Compost Feedstock and Compost Acidification Affect Growth and Mineral Nutrition in Northern Highbush Blueberry
}

\author{
Ryan C. Costello ${ }^{1}$ and Dan M. Sullivan ${ }^{3}$ \\ Department of Crop and Soil Science, Agricultural and Life Science Building \\ 3017, Oregon State University, Corvallis, OR 97331
}

\author{
David R. Bryla \\ U.S. Department of Agriculture, Agricultural Research Service, $3420 \mathrm{NW}$ \\ Orchard Avenue, Corvallis, OR 97330
}

\author{
Bernadine C. Strik and James S. Owen ${ }^{2}$ \\ Department of Horticulture, Agricultural and Life Science Building 4017, \\ Oregon State University, Corvallis, OR 97331
}

Additional index words. Vaccinium corymbosum, elemental sulfur, mulch, douglas fir sawdust, soil amendments

\begin{abstract}
New markets for organic northern highbush blueberry (Vaccinium corymbosum $\mathbf{L}$.) have stimulated interest in using composts specifically tailored to the plant's edaphic requirements. Because composts are typically neutral to alkaline in $\mathrm{pH}$ (pH 7 to 8), and blueberry requires acidic soil (pH 4.2 to 5.5), we investigated elemental sulfur $\left(\mathrm{S}^{0}\right)$ addition as a methodology for reducing compost $\mathrm{pH}$. The objectives were to 1) characterize initial compost chemistry, including the $\mathrm{pH}$ buffering capacity of compost (acidity required to reduce $\mathrm{pH}$ to 5.0 ), 2) measure changes in compost chemistry accompanying acidification, and 3) evaluate plant growth and mineral nutrition of blueberry in soil amended with an untreated or acidified compost. Ten composts prepared from diverse feedstocks were obtained from municipalities and farms. Addition of finely ground $\mathrm{S}^{0}$ reduced compost $\mathbf{p H}$ from 7.2 to 5.3 , on average, after $70 \mathrm{~d}$ at $22{ }^{\circ} \mathrm{C}$, and increased the solubility of nutrients, including $\mathrm{K}$ (from 22 to $36 \mathrm{mmol}^{(+)} / \mathrm{L}$ ), Ca (from 5 to $19 \mathrm{mmol}^{(+)} / \mathrm{L}$ ), $\mathrm{Mg}$ (from 5 to $20 \mathrm{mmol}^{(+)} / \mathrm{L}$ ), and $\mathrm{Na}$ (from 6 to $9 \mathrm{mmol}^{(+)} / \mathrm{L}$ ). Sulfate-S, a product of $\mathrm{S}^{0}$ oxidation, also increased from 5 to $45 \mathrm{mmol}^{(-)} / \mathrm{L}$. The composts were incorporated into soil at a high rate $(30 \% \mathrm{v} / \mathrm{v})$ in a greenhouse trial to evaluate their suitability for use in blueberry production. Shoot and root growth were strongly affected by compost chemical characteristics, including pH and electrical conductivity (EC). Potassium in compost was highly variable $\left(2-32 \mathrm{~g} \mathrm{~kg}^{-1}\right)$. Concentration of $\mathrm{K}$ in the leaves increased positively in response to compost $\mathrm{K}$, whereas shoot dry weight and root growth declined. Leaf $\mathrm{Mg}$ also declined in response to compost $K$, suggesting that elevated $K$ concentrations in compost may cause Mg deficiency. Composts with the highest $\mathrm{K}$ were also high in total $\mathrm{N}$, pH, and EC. Compost acidification to $\mathrm{pH} \leq 6$ improved growth and increased leaf $\mathrm{Mg}$ concentration. On the basis of these results, composts derived from animal manures or young plant tissues (e.g., green leaves) appear to be unsuitable for high-rate applications to blueberry because they usually require high amounts of $S^{0}$ for acidification and are often high in $E C$ and $K$, whereas those derived from woody materials, such as local yard debris, appear promising based on their $\mathrm{C}: \mathrm{N}$ ratio, compost acidification requirement, and $\mathrm{EC}$.
\end{abstract}

Highbush blueberry (Vaccinium sp.) is adapted to acidic soils with high organic matter content (Gough 1994; Haynes and Swift, 1986). Maintaining these conditions is essential for good production in both conventional and organic blueberry plantings (Clark, 1991; Clark and Moore, 1991; Lareau, 1989; Moore, 1979; Strik et al., 2016; White, 2006). Organic matter has been traditionally supplied to blueberry by mulching and amending the soil with woody materials such as coniferous bark and sawdust (Retamales and Hancock, 2012). The use of these materials as a mulch improves soil water retention and reduces the need for herbicides. However, the cost of bark and sawdust are increasing, and most are rich in nutrients that gradually mineralize in the soil for years after application (He et al., 2001; Sikora and Szmidt, 2001; Sullivan et al., 2003). However, composts are ordinarily neutral or alkaline in $\mathrm{pH}$ and frequently contain high amounts of soluble salts. Highbush blueberry grows best at a soil pH of 4.2 to 5.5 (Retamales and Hancock, 2012) and is readily susceptible to salt damage (Machado et al., 2014). Furthermore, composts are often high in $\mathrm{K}$, and excessive $\mathrm{K}$ has been observed to induce $\mathrm{Mg}$ deficiency in highbush blueberry (Eck, 1988; Forge et al., 2013; Krewer and Ruter, 2012). Ideally, a suitable compost for blueberry will contain manageable levels of soluble salts and $\mathrm{K}$ and will not increase soil $\mathrm{pH}$ above 5.5.

Costello and Sullivan (2014) successfully acidified a wide range of composts by adding elemental sulfur $\left(\mathrm{S}^{0}\right)$. The process, which is often used to reduce soil $\mathrm{pH}$ before planting blueberry, is typically rapid in compost (2-6 weeks) and occurs when the $\mathrm{S}^{0}$ is oxidized to sulfuric acid by autotrophic bacteria (e.g., Thiobacillus sp.) and heterotrophic bacteria and fungi (Carrión et al., 2008; García de la Fuente et al., 2007; Germida and Janzen, 1993). The amount of $S^{0}$ required to acidify a compost is a function of its $\mathrm{pH}$ buffering capacity and is usually greater in animal manure composts than in those derived from plant materials (Wong et al., 1998).

The objective of the present study was to identify composts that could be potentially used to amend or replace bark and sawdust in highbush blueberry production systems. Ten composts, produced from locally available organic materials, were evaluated for chemical characteristics, with or without $\mathrm{S}^{0}$ acidification. Plant response to compost was evaluated under controlled greenhouse conditions using potted plants of 'Duke' northern highbush blueberry ( $V$. corymbosum L.). 'Duke' is commonly grown commercially and tends to be sensitive to $\mathrm{N}$ limitations and high soil pH (Strik and Yarborough, 2005; Strik et al., 2014).

\section{Materials and Methods}

Compost feedstocks and sampling. Compost samples originated from on-farm or municipal composting facilities in western Oregon and Washington. Organic materials were composted for a minimum of $90 \mathrm{~d}$ before sample collection. Bulk compost samples $(\approx 100 \mathrm{~L})$ for our research were collected at the end of the summer dry season, when compost curing piles were moist but not saturated. A wide range of feedstocks was represented (Table 1). Bulk composite compost samples were collected from curing piles. Each composite sample comprised 15 subsamples ( 5 to $10 \mathrm{~L}$ per subsample). At some locations, compost was subsampled by opening up the pile with a front-end loader and collecting samples from inside the pile face. In all cases, care was taken not to collect compost that had dried on the outside of the curing piles. After collection, each bulk composite compost sample $(\approx 100 \mathrm{~L})$ was stored in a plastic container 
Table 1. Organic feedstocks used to prepare different composts for northern highbush blueberry.

\begin{tabular}{|c|c|}
\hline Compost & Feedstock sources and mixture \\
\hline Bark:biosolids & $60 \%$ douglas fir bark, $20 \%$ fine sawdust, and $20 \%$ digested, dewatered municipal wastewater treatment biosolids \\
\hline Dairy solids & Dairy solids collected from flushed dairy manure by a mechanical separator \\
\hline Dairy:hops & $80 \%$ dairy solids and $20 \%$ spent hop cones from a brewery \\
\hline Grass:mint & $80 \%$ grass seed hulls from seed cleaning and $20 \%$ peppermint hay (residue from peppermint oil steam extraction) \\
\hline Horse manure & Horse manure with pelletized wood bedding \\
\hline Horse:hay:hops & $45 \%$ scraped horse manure, $45 \%$ spoiled grass hay, and $10 \%$ spent hop cones \\
\hline Leaf & Chipped deciduous tree leaves from municipal street sweeping \\
\hline Mint hay & Peppermint hay \\
\hline Mixed manure & Mixture of horse manure, dairy manure, chicken manure, cereal straw, and douglas fir sawdust \\
\hline Yard debris & Ground urban yard debris (grass, leaves, woody debris) \\
\hline
\end{tabular}

with a loose fitting lid that allowed air entry. Compost subsamples for laboratory analysis $(10 \mathrm{~L})$ were collected by spreading out the 100 -L bulk compost sample on a tarp and then systematically subsampling it. Before chemical and physical analyses (Table 2), compost subsamples were stored indoors at room temperature $\left(22^{\circ} \mathrm{C}\right)$ for up to $30 \mathrm{~d}$.

Compost nutrient analyses $(\mathrm{n}=1)$ were performed by the Oregon State University Central Analytical Laboratory in Corvallis, OR (Table 2; Gavlak et al., 2005). Except as noted, compost samples were dry-ashed at $500{ }^{\circ} \mathrm{C}$ and analyzed for total $\mathrm{P}, \mathrm{K}, \mathrm{Ca}, \mathrm{Mg}$, $\mathrm{B}, \mathrm{Cu}, \mathrm{Mn}$, and $\mathrm{Zn}$ using an inductively coupled plasma (ICP) spectrophotometer. Total C and $\mathrm{N}$ were determined by combustion analysis. Ammonium and $\mathrm{NO}_{3}-\mathrm{N}$ were extracted with $2 \mathrm{M} \mathrm{KCl}$ and determined via automated colorimetric methods. The sum of cations $(\mathrm{Ca}, \mathrm{Mg}, \mathrm{K})$ was calculated by dividing total cation analyses $\left(\mathrm{g} \cdot \mathrm{kg}^{-1}\right)$ by the equivalent weights of a mole of positive charge $\left(20 \mathrm{~g} \cdot \mathrm{mol}^{-1}\right.$ for $\mathrm{Ca}, 12.1 \mathrm{~g} \cdot \mathrm{mol}^{-1}$ for $\mathrm{Mg}$, and $39 \mathrm{~g} \cdot \mathrm{mol}^{-1}$ for $\left.\mathrm{K}\right)$. Compost $\mathrm{pH}$ and $\mathrm{EC}$ were determined by the 1:10 (compost:water; w/w) method in our laboratory. Compost bulk density was determined by filling a 3-L plastic beaker with moist compost and measuring sample volume and weight after dropping the beaker six times from a height of $0.6 \mathrm{~m}$ above a hard surface (Thompson et al., 2001). The compost bulk density measurement was performed on a moist compost sample and then expressed on a dry weight basis. For the greenhouse exper-

Received for publication 22 Oct. 2018. Accepted for publication 22 Mar. 2019.

This research was supported in part by the U.S. Department of Agriculture National Institute of Food and Agriculture (Formula Grant OREI 200851300004443) and our industry contributors.

Mention of trademark, proprietary product, or vendor does not constitute a guarantee or warranty of the product by Oregon State University or the U.S. Department of Agriculture and does not imply its approval to the exclusion of other products or vendors that also may be suitable.

${ }^{1}$ Former graduate student. Current address: 2109 Rimrock Court, Olympia, WA 98512.

${ }^{2}$ Current address: Virginia Polytechnic Institute and State University, School of Plant and Environmental Sciences, Hampton Roads Agricultural Research and Extension Center, 1444 Diamond Springs Road, Virginia Beach, VA 23455.

${ }^{3}$ Corresponding author. E-mail: dan.sullivan@ oregonstate.edu. iment, the total $\mathrm{N}$ and mineral $\mathrm{N}$ applied per pot were estimated from compost $\mathrm{N}$ analyses ( $\mathrm{g} \cdot \mathrm{kg}^{-1}$; Table 2 ) based on the bulk density of each compost ( $\mathrm{g} \cdot \mathrm{L}^{-1}$ dry compost) and by the volume of compost added to the pots $(0.7 \mathrm{~L} / \mathrm{pot})$.

Additional measurements were performed to determine the stability of compost organic matter $\left(\mathrm{CO}_{2}-\mathrm{C}\right.$ respired $)$ and the quantity of $\mathrm{N}$ mineralized from compost (Table 2). Moist compost was incubated with moist Willamette silt loam [a fine-silty, mixed, superactive mesic Pachic Ultic Argixeroll; U.S. Department of Agriculture (USDA) National Resources Conservation Service, 2006] soil $\left(200 \mathrm{~mL} \cdot \mathrm{kg}^{-1}\right.$ dry soil) for determination of cumulative net respiration $\left(21 \mathrm{~d}\right.$ at $\left.22^{\circ} \mathrm{C}\right)$ and cumulative $\mathrm{N}$ mineralization $\left(30 \mathrm{~d}\right.$ at $\left.22{ }^{\circ} \mathrm{C}\right)$ using a no-compost control soil as the baseline measurement. Willamette silt loam soil was also used for the greenhouse trial. Respiration was quantified using an alkaline trap method (Anderson, 1982), and cumulative $\mathrm{N}$ mineralized $\left(\mathrm{NH}_{4}+\mathrm{NO}_{3}\right)$ was determined via colorimetry (Gavlak et al., 2005).

Compost acidification. Compost buffering capacity (CBC), defined as the quantity of acidity needed to reduce $\mathrm{pH}$ by one unit (Table 3), was determined using a titration method (Costello and Sullivan, 2014). Titrations were performed with dilute $\mathrm{H}_{2} \mathrm{SO}_{4}$ at six rates $\left(0.3\right.$ to $2 \mathrm{~mol} \mathrm{H}^{+}$per $\mathrm{kg}$ of compost-C). Each rate of dilute $\mathrm{H}_{2} \mathrm{SO}_{4}$ addition was replicated twice. Five grams of compost was equilibrated in a 1:10 ratio of compost: liquid $(\mathrm{w} / \mathrm{w})$, and $\mathrm{pH}$ and $\mathrm{EC}$ were measured after $72 \mathrm{~h}$. The CBC for each compost was calculated as the negative reciprocal of the slope of the linear regression between compost $\mathrm{pH}$ and acid addition rate. The quantity of $\mathrm{S}^{0}$ required $\left(\mathrm{S}_{\mathrm{req}}\right)$ to acidify the compost to a target $\mathrm{pH}$ of 5.0 was calculated as:

$$
\begin{aligned}
\mathrm{S}_{\mathrm{req}}= & {[\text { initial compost } \mathrm{pH}-\operatorname{target} \mathrm{pH}(5)] } \\
& \times \mathrm{CBC} \times \mathrm{S}_{\mathrm{eq}},
\end{aligned}
$$

where $\mathrm{CBC}$ equals the mol of $\mathrm{H}^{+}$per $\mathrm{kg}$ compost- $\mathrm{C}$ (from linear regression) and $\mathrm{S}_{\mathrm{eq}}$ is the equivalent weight of $\mathrm{S}^{0}\left(16 \mathrm{~g} \mathrm{~S}^{0}\right.$ per $\left.\mathrm{mol} \mathrm{H}^{+}\right)$.

To prepare acidified compost for the greenhouse experiment, $\mathrm{S}^{0}$ was added to moist compost and then stored for $70 \mathrm{~d}$ at $22{ }^{\circ} \mathrm{C}$ (indoor room temperature). Composts were amended with $\mathrm{S}^{0}$ at a single addition rate $\left[32 \mathrm{~g} \mathrm{~S}^{0}\right.$ (or $2 \mathrm{~mol} \mathrm{H}^{+}$) per $\mathrm{kg}$ of compost-C], which was based on the average $\mathrm{S}_{\text {req }}\left(30 \mathrm{~g} \mathrm{~S}^{0}\right.$ per $\mathrm{kg}$ compost-C) of the composts. On a volumetric basis, $\approx 2 \mathrm{~g} \cdot \mathrm{L}^{-1} \mathrm{~S}^{0}$ was added. The $\mathrm{S}^{0}(0 \mathrm{~N}-0 \mathrm{P}-$
0K-90S; Tiger 90 CR, Alberta, Canada) was ground into a powder with a mortar and pestle before mixing with compost. At mixing, water was added until the compost was moist by feel (an average of $550 \mathrm{~mL} \cdot \mathrm{kg}^{-1}$ in moist compost). Composts were then stored in 15-L buckets with lids. Each bucket lid had three $0.5-\mathrm{cm}$ holes to allow air entry.

Acidified and non-acidified composts were subsampled for chemical analyses immediately after $70 \mathrm{~d}$ of storage (Table 3 ). Each compost sample collected for these analyses represented more than $5 \%$ of the compost volume used in the greenhouse experiment. Compost $\mathrm{pH}$ and EC were determined by the $1: 10$ (compost:water; w/w) method in our laboratory. Soluble nutrients were extracted from compost at a commercial laboratory (Brookside Laboratories, New Bremen, $\mathrm{OH}$ ) using an adaptation of the saturated media extract method (Warncke, 1986). To do so, a 200-g "as-is" compost sample (not dried or ground) was moistened to saturation (when the compost began to flow when tilted and had minimal free water on the surface) and then extracted by filtration under vacuum. Soluble nutrients in the extract were determined by an ICP spectrophotometer in $\mathrm{mg} / \mathrm{L}$ and converted to mmol. $\mathrm{L}^{-1}$ ( + or - ), based on equivalent weight of a millimole of positive or negative charge.

Greenhouse experiment. The greenhouse experiment was conducted in a glasshouse located at the USDA Agricultural Research Service Horticultural Crops Research Laboratory in Corvallis, OR. One-year-old 'Duke' blueberry plants were obtained in 50-cell flats $\left(5-\mathrm{cm}^{2}\right.$ cells) from a commercial nursery (Fall Creek Farm \& Nursery, Lowell, OR) and transplanted into 2.4-L black polyethylene pots $(15.2 \mathrm{~cm}$ diameter $\times 12.4 \mathrm{~cm}$ deep $)$ on 17 Feb. 2010. Plants were not removed from their nursery media [which contained peat and decomposed douglas fir (Pseudotsuga menziesii) bark] during transplanting to avoid damaging the root system. The pots were filled with one of 12 compost treatments, with or without $\mathrm{S}^{0}$ added to each for acidification (a total of 24 treatments). The compost treatments included 10 soil-compost mixes, one soil-sawdust mix (industry standard), and one soil only control. Each mix contained six parts soil (air-dry), three parts compost or sawdust (air dry), and one part pumice, by volume. Pumice $(10 \%)$ was incorporated for drainage and was also added to the soil only treatment. Initial $\mathrm{pH}$ of the soil was 


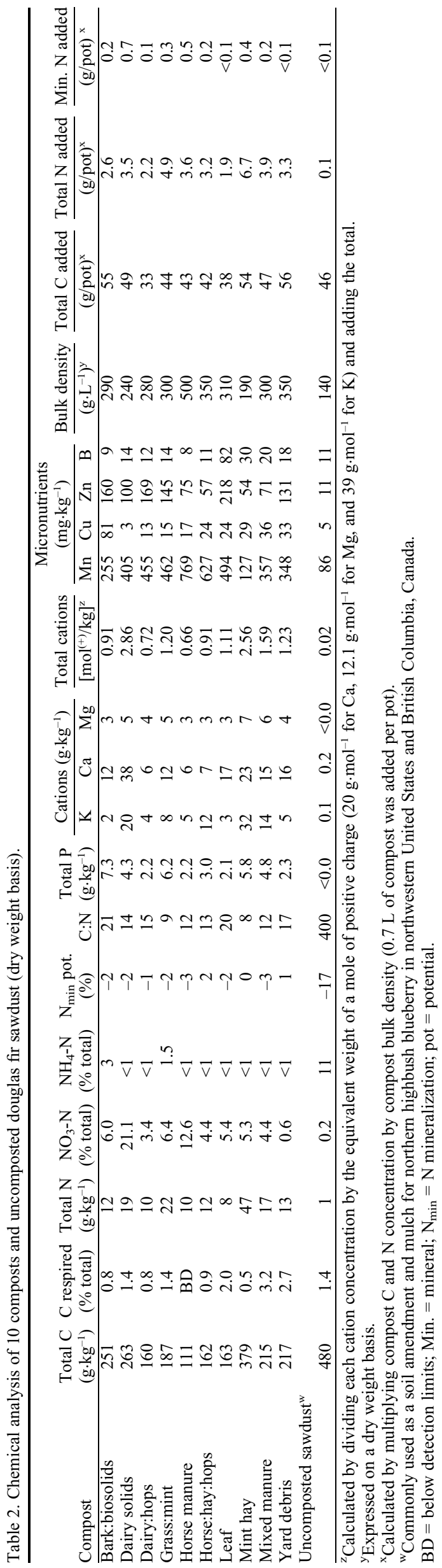

5.4 , and the organic matter content was $4.1 \%$. The $\mathrm{S}^{0}$ was added at potting to acidify sawdust and soil only treatments at a rate of $1.4 \mathrm{~g} /$ pot, which approximated the average amount of $\mathrm{S}^{0}$ added to the pots with acidified compost as already described.

The pots were arranged on a bench in the glasshouse in a randomized complete block design, with five replicates per treatment. The replicates were blocked to minimize variation in lighting and air movement. Air temperature in the glasshouse averaged $20{ }^{\circ} \mathrm{C}$ during the experiment and reached a maximum of $33{ }^{\circ} \mathrm{C}$ and a minimum of $13{ }^{\circ} \mathrm{C}$. The readings were recorded every $15 \mathrm{~min}$ with a data logger (model LI-1400; LI-COR Biosciences, Lincoln, NE) and measured using a temperature sensor (model 1400-101; LI-COR Biosciences) located near the top of the plant canopy. Supplemental lighting was provided by $1000-\mathrm{W}$ high-pressure sodium lamps set to turn on at $0600 \mathrm{HR}$ and turn off at $1800 \mathrm{HR}$. Plants were watered by hand three times per week with $200 \mathrm{~mL}$ of water and were fertigated every $14 \mathrm{~d}$, starting at $7 \mathrm{~d}$ after transplanting (DAT), with $200 \mathrm{~mL}$ of fertilizer solution (Miracle-Gro Water Soluble Azalea, Camellia, Rhododendron Plant Food, Marysville, OH). The fertilizer contained $3 \% \mathrm{NH}_{4}-\mathrm{N}$ and $27 \%$ urea-N, and was composed primarily of $\left(\mathrm{NH}_{4}\right) \mathrm{H}_{2} \mathrm{PO}_{4}$, $\left(\mathrm{NH}_{2}\right)_{2} \mathrm{CO}, \mathrm{KH}_{2} \mathrm{PO}_{4}$, and $\mathrm{KCl}$. A total of $70 \mathrm{mg}$ of $\mathrm{N}$ was applied to each plant during the study.

Plants were dormant when transplanted. Bud break took place starting at 7 DAT. Pourthrough leachate was collected and analyzed for EC at 10 and 50 DAT. Leachate was produced by applying $150 \mathrm{~mL}$ of water per pot at $1 \mathrm{~h}$ after the plants were irrigated. Leachate temperature was $20^{\circ} \mathrm{C}$ when EC was determined.

Plants were destructively harvested at 78 DAT. Each plant was partitioned into stems and leaves, oven-dried at $70{ }^{\circ} \mathrm{C}$, and weighed. Nitrogen in harvested leaves was determined by combustion analysis, and other nutrients via ICP spectroscopy, following acid digestion (Gavlak et al., 2005). At harvest, a soil sample was collected from the pots by discarding a 5 -cm depth of soil from the top and bottom of each pot, compositing the remaining soil, and collecting a $60-\mathrm{cm}^{3}$ subsample for $\mathrm{pH}$ and $\mathrm{EC}$ determination (1 soil : 2 water method; Gavlak et al., 2005).

At harvest, root development was assessed by measuring the distance roots spread into the pots from the original transplant plug. Rooting distance was measured laterally in four directions from the plug, and downward from the plug, and then averaged. The rooting distance rating was equal to 1 when 0 to $1 \mathrm{~cm}$ of new root growth was present, 2 to 6 (in 1-cm increments) when 2 to $6 \mathrm{~cm}$ was of new growth were present, and was equal to 7 when more than $6 \mathrm{~cm}$ of new growth were present.

Statistical analysis. The main effects of compost and acidification and the interaction (compost $\times$ acidification) were evaluated by analysis of variance using Proc GLM (general linear model) with Statistical Analysis 
Software (SAS Institute, Cary, NC). Means were separated at $P \leq 0.05$ using Tukey's honestly significant difference test, and groups of treatments were compared by contrast analysis using the CONTRAST statement. Linear regression analysis was done using SigmaPlot v. 13.0 (SPSS, Chicago, IL). The relationship between soil $\mathrm{pH}$ and shoot dry weight was segmented and hence analyzed using two-segment piecewise regression (Bates and Watts, 1988). The breakpoint was defined by the $\mathrm{pH}$ where the fitted functions intersected and was interpreted as the critical value beyond which the plants were severely stunted by high $\mathrm{pH}$ composts. Spearman's rank correlations were calculated to assess all relationships between key compost traits (total $\mathrm{N}$ concentration, $\mathrm{pH}, \mathrm{EC}$, and total and soluble $\mathrm{K}$ concentrations) and plant growth.

\section{Results and Discussion}

\section{Initial compost chemistry}

Compost $C$ and organic matter added to soil. Across composts, compost $\mathrm{C}$ averaged $210 \mathrm{~g} \cdot \mathrm{kg}^{-1}$ and ranged from 111 to $379 \mathrm{~g} \cdot \mathrm{kg}^{-1}$ (Table 2). Compost organic matter, which is equivalent to about twice the $\mathrm{C}$ analysis value (Sullivan and Miller, 2001) averaged $422 \mathrm{~g} \cdot \mathrm{kg}^{-1}$. The addition of compost increased soil organic matter in pots by an average of $6.0 \%$ by weight [calculated from compost C multiplied by 2 , and the volume and dry bulk density measurements of the soil $\left(1.4 \mathrm{~L} /\right.$ pot and $1.0 \mathrm{~kg} \cdot \mathrm{L}^{-1}$, respectively) and composts $(0.7 \mathrm{~L} /$ pot and $0.2-0.5 \mathrm{~kg} \cdot \mathrm{L}^{-1}$, Table 2 ) respectively].

Field trials in western Oregon and Washington using composts similar to some of those used in the present study have demonstrated their ability to increase soil organic matter, without increasing $\mathrm{pH}$ significantly or providing excessive soluble salts and mineral N. For example, in Oregon, yard debris composts were applied as mulch (not incorporated) in two separate trials on a silt loam soil (Sullivan and Bell, 2015; Sullivan et al., 2015). In both field trials, surface application of yard debris

Table 3. Compost acidification and chemical characteristics of 10 untreated $\left(-\mathrm{S}^{0}\right)$ and sulfur-acidified $\left(+\mathrm{S}^{0}\right)$ composts. $^{\mathrm{z}}$

\begin{tabular}{|c|c|c|c|c|c|c|c|c|c|c|c|c|c|c|c|c|c|c|c|c|c|c|}
\hline \multirow[b]{3}{*}{ Compost } & \multicolumn{2}{|c|}{ Compost acidification $^{y}$} & \multirow{2}{*}{\multicolumn{2}{|c|}{$\mathrm{pH}^{\mathrm{x}}$}} & \multirow{2}{*}{\multicolumn{2}{|c|}{$\begin{array}{c}E^{\mathrm{x}} \\
\left(\mathrm{dS} \cdot \mathrm{m}^{-1}\right)> \\
\end{array}$}} & \multicolumn{14}{|c|}{ Soluble nutrients $\left[\mathrm{mmol}^{(+o r-)} / \mathrm{L}\right]^{\mathrm{w}}$} & \multirow{2}{*}{\multicolumn{2}{|c|}{$\begin{array}{c}\text { Total } \\
\text { charge } \\
\left(\mathrm{mmol} \cdot \mathrm{L}^{-1}\right)^{\mathrm{v}}\end{array}$}} \\
\hline & \multirow{2}{*}{$\begin{array}{c}\mathrm{pH} \text { buffering } \\
\text { capacity (mol H} \mathrm{H}^{+} \\
\text {per kg compost-C) }\end{array}$} & \multirow{2}{*}{$\begin{array}{c}\mathrm{S}^{0} \text { required to } \\
\text { reduce } \mathrm{pH} \text { to } 5.0 \\
\text { (g per kg compost-C) }\end{array}$} & & & & & \multicolumn{2}{|c|}{$\mathrm{K}$} & \multicolumn{2}{|c|}{$\mathrm{Ca}$} & \multicolumn{2}{|c|}{$\mathrm{Mg}$} & \multicolumn{2}{|c|}{$\mathrm{Na}$} & \multicolumn{2}{|c|}{$\mathrm{SO}_{4}-\mathrm{S}$} & \multicolumn{2}{|c|}{$\mathrm{NO}_{3}-\mathrm{N}$} & \multicolumn{2}{|c|}{$\mathrm{NH}_{4}-\mathrm{N}$} & & \\
\hline & & & $-\mathrm{S}^{0}$ & $+\mathrm{S}^{0}$ & $-\mathrm{S}^{0}$ & $+\mathrm{S}^{0}$ & $\overline{\mathrm{S}^{0}}$ & $+\mathrm{S}^{0}$ & $-\mathrm{S}^{0}$ & $+\mathrm{S}^{0}$ & $\overline{-\mathrm{S}^{0}}$ & $\overline{+\mathrm{S}^{0}}$ & $-\mathrm{S}^{0}$ & $+\mathrm{S}^{0}$ & $\overline{-\mathrm{S}^{0}}$ & $\overline{+\mathrm{S}^{0}}$ & $\overline{-S^{0}}$ & $\overline{+\mathrm{S}^{0}}$ & $-\mathrm{S}^{0}$ & $+\mathrm{S}^{0}$ & $-\mathrm{S}^{0}$ & $+\mathrm{S}^{0}$ \\
\hline Bark:biosolids & 0.85 & 5 & 5.4 & 4.3 & 0.9 & 1.7 & 3 & 3 & 12 & 22 & 6 & 12 & 2 & 2.5 & 10 & 28 & 2 & 1 & 0.6 & 0.2 & 36 & 69 \\
\hline Dairy:hops & 0.78 & 35 & 7.8 & 5.2 & 0.6 & 1.8 & 9 & 13 & 5 & 19 & 5 & 17 & 10 & 12 & 1 & 41 & 8 & 2 & $<0.1$ & 0.1 & 38 & 104 \\
\hline Grass:mint & 0.89 & 10 & 5.7 & 4.3 & 2.2 & 3.8 & 29 & 35 & 10 & 25 & 18 & 40 & 4 & 3.8 & 12 & 45 & 9 & 6 & 0.1 & 0.7 & 82 & 156 \\
\hline Horse manure & 1.13 & 25 & 6.4 & 4.9 & 1.1 & 2.0 & 24 & 30 & 9 & 22 & 10 & 31 & 7 & 9 & 7 & 42 & 7 & 2 & 0.3 & 0.1 & 64 & 136 \\
\hline Mixed manure & 0.81 & 38 & 7.9 & 6.0 & 1.7 & 4.0 & 20 & 50 & 2 & 18 & 2 & 21 & 6 & 15 & 5 & 58 & 0 & 2 & $<0.1$ & 0.4 & 35 & 164 \\
\hline Yard debris & 0.65 & 28 & 7.7 & 6.1 & 0.8 & 1.6 & 12 & 17 & 4 & 20 & 2 & 12 & 3 & 3.7 & 1 & 40 & 1 & 0 & $<0.1$ & 0.5 & 23 & 93 \\
\hline Average & 0.85 & 30 & 7.2 & 5.3 & 1.9 & 3.5 & 22 & 36 & 5 & 19 & 5 & 20 & 6 & 9 & 5 & 45 & 3 & 3 & & 0.4 & 48 & 133 \\
\hline $\begin{array}{c}P \text { value for } \\
t \text { test }\end{array}$ & - & - & $<0$. & 001 & & & & 020 & $<0$. & & $<0$ & 001 & & vs & $<0$ & & $\mathrm{~N}$ & & 0.0 & & & \\
\hline
\end{tabular}

${ }^{\mathrm{z}}$ Elemental sulfur $\left(\mathrm{S}^{\circ}\right)$ was added to each compost at a rate of $32 \mathrm{~g}\left(\right.$ or $\left.2 \mathrm{~mol} \mathrm{H}^{+}\right)$per kg of compost-C. The composts were then incubated for $70 \mathrm{~d}$ at $22{ }^{\circ} \mathrm{C}$ before determination of $\mathrm{pH}, \mathrm{EC}$, and soluble nutrients.

${ }^{\mathrm{y}}$ Compost acidification requirement $\left(\mathrm{S}_{\text {req }}\right)$ was determined by titration of compost with dilute sulfuric acid (Costello and Sullivan, 2014; Eq. [1]).

${ }^{\mathrm{x}} \mathrm{pH}$ and EC were determined by the 1:10 (compost to water; w/w) method.

${ }^{\text {w}}$ Soluble nutrients were extracted from compost at a commercial laboratory (Brookside Laboratories, New Bremen, $\mathrm{OH}$ ) using an adaptation of the saturated media extract method (Warncke, 1986).

${ }^{\mathrm{v}}$ Total charge equals the sum of cations $\left(\mathrm{mmol}^{(+)}\right)$and anions $\left(\mathrm{mmol}^{(-)}\right)$per $\mathrm{L}$ of saturated extract.

NS = nonsignificant.

Table 4. Soil $\mathrm{pH}$ and the electrical conductivity of leachate and soil in pots of 'Duke' blueberry plants. The plants were grown in soil amended with untreated (-S $\left.{ }^{0}\right)$ or sulfur-acidified $\left(+\mathrm{S}^{0}\right)$ compost or douglas fir sawdust (industry standard), or in soil only.

\begin{tabular}{|c|c|c|c|c|c|c|c|c|c|c|}
\hline \multirow[b]{4}{*}{ Soil amendment } & & & & \multicolumn{7}{|c|}{ Electrical conductivity $\left(\mathrm{dS} \cdot \mathrm{m}^{-1}\right)$} \\
\hline & & & & \multicolumn{6}{|c|}{ Pour-through leachate } & \multirow[b]{2}{*}{ Soil at 78 DAT } \\
\hline & \multicolumn{3}{|c|}{ Soil $\mathrm{pH}$ at $78 \mathrm{DAT}$} & \multicolumn{3}{|c|}{$10 \mathrm{DAT}$} & \multicolumn{3}{|c|}{$50 \mathrm{DAT}$} & \\
\hline & $-\mathrm{S}^{0}$ & $+\mathrm{S}^{0}$ & $\overline{\text { Difference }}$ & $-\mathrm{S}^{0}$ & $+\mathrm{S}^{0}$ & Difference & $-\mathrm{S}^{0}$ & $+\mathrm{S}^{0}$ & Difference & $-\mathrm{S}^{0}$ \\
\hline \multicolumn{11}{|l|}{ Compost } \\
\hline Bark:biosolids & $5.4 \mathrm{e}$ & $4.6 \mathrm{e}$ & $-0.7 * * *$ & $1.1 \mathrm{~cd}$ & $2.4 \mathrm{~d}$ & $1.4 * * *$ & $0.2 \mathrm{efg}$ & $0.8 \mathrm{~cd}$ & $0.6 * * *$ & $0.2 \mathrm{bcd}$ \\
\hline Dairy solids & $7.0 \mathrm{a}$ & $6.7 \mathrm{a}$ & $-0.4 * * *$ & $4.1 \mathrm{a}$ & $4.8 \mathrm{a}$ & $0.7 * * *$ & $1.2 \mathrm{a}$ & $1.4 \mathrm{a}$ & $0.2 * *$ & $0.4 \mathrm{a}$ \\
\hline Dairy:hops & $5.8 \mathrm{~cd}$ & $5.0 \mathrm{bcd}$ & $-0.7 * * *$ & 0.7 defg & $1.9 \mathrm{de}$ & $1.3 * * *$ & $0.3 \mathrm{de}$ & $0.7 \mathrm{de}$ & $0.3 * * *$ & $0.2 \mathrm{abcd}$ \\
\hline Grass:mint & $5.5 \mathrm{de}$ & $5.0 \mathrm{~cd}$ & $-0.5 * * *$ & $2.2 \mathrm{~b}$ & $3.9 \mathrm{~b}$ & $1.7 * * *$ & $0.7 \mathrm{~b}$ & $1.0 \mathrm{bc}$ & $0.4 * * *$ & $0.3 \mathrm{abcd}$ \\
\hline Horse manure & $5.5 \mathrm{de}$ & 4.9 cde & $-0.6 * * *$ & $1.6 \mathrm{bc}$ & $3.3 \mathrm{c}$ & $1.7 * * *$ & $0.5 \mathrm{~cd}$ & $1.0 \mathrm{bc}$ & $0.6 * * *$ & $0.3 \mathrm{abc}$ \\
\hline Horse:hay:hops & $5.7 \mathrm{~cd}$ & $5.1 \mathrm{bcd}$ & $-0.7 * * *$ & $1.7 \mathrm{~b}$ & $3.5 \mathrm{bc}$ & $1.8 * * *$ & $0.6 \mathrm{bc}$ & $1.1 \mathrm{~b}$ & $0.5 * * *$ & $0.4 \mathrm{ab}$ \\
\hline Leaf & $5.7 \mathrm{~cd}$ & $5.2 \mathrm{bc}$ & $-0.6 * * *$ & 0.4 efg & $1.7 \mathrm{e}$ & $1.3 * * *$ & $0.3 \mathrm{def}$ & $0.6 \mathrm{e}$ & $0.3 * * *$ & $0.2 \mathrm{bcd}$ \\
\hline Mint hay & $5.9 \mathrm{c}$ & $5.2 \mathrm{bc}$ & $-0.8 * * *$ & $2.1 \mathrm{~b}$ & $5.3 \mathrm{a}$ & $3.2 * * *$ & $0.7 \mathrm{~b}$ & $1.5 \mathrm{a}$ & $0.8 * * *$ & $0.5 \mathrm{a}$ \\
\hline Mixed manure & $6.4 \mathrm{~b}$ & $5.4 \mathrm{~b}$ & $-1.1 * * *$ & $1.0 \mathrm{de}$ & $3.5 \mathrm{bc}$ & $2.5 * * *$ & 0.3 def & $1.0 \mathrm{bc}$ & $0.7 * * *$ & $0.3 \mathrm{abcd}$ \\
\hline Yard debris & $6.0 \mathrm{c}$ & $5.1 \mathrm{bc}$ & $-0.9 * * *$ & $0.7 \mathrm{def}$ & $2.4 \mathrm{~d}$ & $1.7 * * *$ & $0.3 \mathrm{ef}$ & $1.0 \mathrm{bc}$ & $0.8 * * *$ & $0.3 \mathrm{abcd}$ \\
\hline Sawdust & $5.5 \mathrm{de}$ & $4.8 \mathrm{de}$ & $-0.7 * * *$ & $0.1 \mathrm{~g}$ & $0.2 \mathrm{f}$ & $0.1^{\mathrm{NS}}$ & $0.1 \mathrm{~g}$ & $0.3 \mathrm{f}$ & $0.3 * * *$ & $0.1 \mathrm{~d}$ \\
\hline Soil only & $5.4 \mathrm{e}$ & $4.6 \mathrm{e}$ & $-0.8 * * *$ & $0.2 \mathrm{fg}$ & $0.5 \mathrm{f}$ & $0.3^{\mathrm{NS}}$ & $0.2 \mathrm{fg}$ & $0.8 \mathrm{~d}$ & $0.6 * * *$ & $0.1 \mathrm{~cd}$ \\
\hline Average & 5.8 & 5.1 & & 1.3 & 2.8 & & 0.4 & 0.9 & & 0.4 \\
\hline \multicolumn{11}{|l|}{ Significance } \\
\hline Soil amendment & \multicolumn{3}{|c|}{$<0.001$} & \multicolumn{3}{|c|}{$<0.001$} & \multicolumn{3}{|c|}{$<0.001$} & $<0.001$ \\
\hline $\mathrm{S}^{\circ}$ acidification & \multicolumn{3}{|c|}{$<0.001$} & \multicolumn{3}{|c|}{$<0.001$} & \multicolumn{3}{|c|}{$<0.001$} & $<0.001$ \\
\hline Interaction & \multicolumn{3}{|c|}{0.001} & \multicolumn{3}{|c|}{$<0.001$} & & $<0.001$ & & NS \\
\hline Contrasts & & & & & & & & & & \\
\hline All composts vs. soil only & & $<0.001$ & & & $<0.001$ & & & $<0.001$ & & $<0.001$ \\
\hline Sawdust vs. soil only & & NS & & & NS & & & $<0.001$ & & NS \\
\hline
\end{tabular}

${ }^{\mathrm{z}}$ Means followed by the same letter within a column are not significantly different at $P \leq 0.05(\mathrm{n}=5)$.

NS, *,**,***Nonsignificant or significant at $P \leq 0.05,0.01$, or 0.001 , respectively.

$\mathrm{DAT}=$ days after transplanting. 
compost increased soil organic matter from 31 to $47 \mathrm{~g} \cdot \mathrm{kg}^{-1}(0-20 \mathrm{~cm}$ depth$)$ within $2-4$ years. The net increase in soil organic matter in these earlier trials accounted for $18 \%$ to $30 \%$ of compost organic matter applied. Likewise, in Washington, composted yard/food waste significantly increased soil $\mathrm{C}$ relative to no compost, following a high rate of application to a fine sandy loam soil (Sullivan et al., 2003). The net increase of soil $C$ in this case was equal to $35 \%$ of applied compost-C at 3 years after application, $20 \%$ at 6 years, and $18 \%$ at 7 years.

Compost $N$. Total $\mathrm{N}$ added by compost ranged from 1.9 to $6.7 \mathrm{~g} / \mathrm{pot}$ and averaged $3.6 \mathrm{~g} /$ pot, whereas total $\mathrm{N}$ added by sawdust was $<0.1 \mathrm{~g} /$ pot. Mineral $\mathrm{N}$ ranged from $4 \%$ to $21 \%$ of the total $\mathrm{N}$ present in the composts (Table 2).

Nitrogen mineralization potential was negligible and near zero in each compost (Table 2). Plant-available $\mathrm{NO}_{3}-\mathrm{N}$ mineralized from compost during a 21-d incubation period in soil ranged from -0.1 to $0.1 \mathrm{~g} / \mathrm{pot}$ and averaged $-0.04 \mathrm{~g} /$ pot (data not shown). In contrast, sawdust was deficient in $\mathrm{N}$, as indicated by the high $\mathrm{C}: \mathrm{N}$ ratio (480; Table 2) and a negative $\mathrm{N}$ mineralization potential $(-17 \%)$.

Compost C: $N$ ratio. Compost $\mathrm{C}: \mathrm{N}$ was a rough indicator of the mineral $\mathrm{N}$ supplied by compost. Composts with $\mathrm{C}: \mathrm{N}$ ratios $<15$ supplied an average of $0.4 \mathrm{~g}$ of mineral $\mathrm{N}$ per pot, whereas those with $\mathrm{C}: \mathrm{N}$ ratios $\geq 15$ supplied $\leq 0.2 \mathrm{~g}$ of mineral $\mathrm{N}$ (Table 2). To increase soil organic matter without supplying excessive soluble salts, Sullivan et al. (2014) recommended choosing a compost with a $\mathrm{C}: \mathrm{N}$ ratio of 15 to 25 , which usually corresponds to 10 to $20 \mathrm{~g} \cdot \mathrm{kg}^{-1}$ total $\mathrm{N}$ in compost dry matter. Such composts typically mineralize $-5 \%$ to $5 \%$

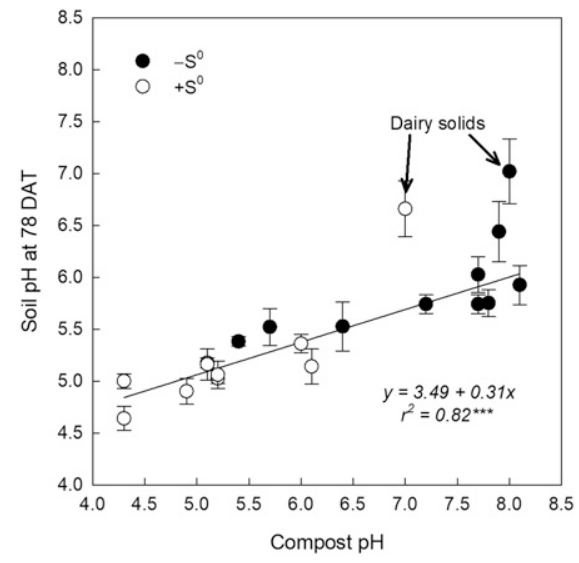

Fig. 1. Relationship between initial compost $\mathrm{pH}$ (1:10 method) and soil $\mathrm{pH}(1: 2$ method) determined at $78 \mathrm{~d}$ after transplanting (DAT). Composts were untreated $\left(-\mathrm{S}^{0}\right)$ or acidified $\left(+\mathrm{S}^{0}\right)$ by adding $32 \mathrm{~g}$ of elemental $\mathrm{S}$ per $\mathrm{kg}$ compost-C. Data points for dairy solids compost were outside of the confidence interval for the regression equation and therefore were considered outliers and excluded from the regression dataset. Once adjusted, the regression was significant at $P<$ $0.001(* * *)$. Error bars indicate standard deviation of the mean $(\mathrm{n}=5)$. of compost total $\mathrm{N}$ in the first summer following application, with annual mineralization equivalent to $5 \%$ of compost total $\mathrm{N}$ in the second through fourth year after application (Bary et al., 2016).

Compost stability. Organic matter was stable and resistant to further decomposition in the composts, by virtue of the fact that $\mathrm{C}$ respiration, $\mathrm{C}: \mathrm{N}$ ratio, and ratio of $\mathrm{NH}_{4}-\mathrm{N}$ to $\mathrm{NO}_{3}-\mathrm{N}$ were all low in each compost (Table 2). Stability, as indicated by the amount of $\mathrm{CO}_{2}$ respired during a 21 -d incubation in soil, was $\leq 3 \%$ in each compost. Compost C:N ratios averaged 14 and were similar to those reported for stable soil C (C:N of 10-12; Stevenson 1994). The ratio of $\mathrm{NH}_{4}-\mathrm{N}$ to $\mathrm{NO}_{3}-\mathrm{N}$ in compost is an indirect indicator of compost stability, with ratios $<1$ indicating stability (Sullivan and Miller, 2001). Our composts had $\mathrm{NH}_{4}-\mathrm{N}$ to $\mathrm{NO}_{3}-\mathrm{N}$ ratios of $<0.5$.

Compost $K$ and $M g$. Compost total $\mathrm{K}$ varied among composts, ranging from 2 to $32 \mathrm{~g} \cdot \mathrm{kg}^{-1}$, whereas the range of compost $\mathrm{Mg}$ concentrations was more limited $\left(3-7 \mathrm{~g} \cdot \mathrm{kg}^{-1}\right)$. As a result, differences in compost $\mathrm{K}: \mathrm{Mg}$ ratio were largely due to variability in $\mathrm{K}$ concentration. Compost $\mathrm{K}: \mathrm{Mg}$ ratios $(\mathrm{w} / \mathrm{w})$ ranged from 0.7 to 4.6. Composts with $\mathrm{K}: \mathrm{Mg}$ ratios greater than 2 included mixed manure (2.3), horse:hay:hops and dairy solids (4.0), and mint hay (4.6), whereas those with the lowest ratios were bark:biosolids (0.7), dairy:hops and leaf (1.0), and yard debris (1.3). Compost total $\mathrm{K}$ concentration was also positively correlated to total $\mathrm{N}$ concentration in the composts $\left(r^{2}=0.77 ; P<0.001 ; \mathrm{n}=10\right)$.

Compost micronutrients. The concentrations of micronutrients in the compost averaged $430 \mathrm{mg} \cdot \mathrm{kg}^{-1} \mathrm{Mn}, 28 \mathrm{mg} \cdot \mathrm{kg}^{-1} \mathrm{Cu}, 118 \mathrm{mg} \cdot \mathrm{kg}^{-1}$ $\mathrm{Zn}$, and $22 \mathrm{mg} \cdot \mathrm{kg}^{-1} \mathrm{~B}$ (Table 2). Leaf compost was high in B (82 ppm) and $\mathrm{Zn}(218 \mathrm{ppm})$ relative to the average value for all composts. The bark:biosolids had high $\mathrm{Cu}$ (81 ppm), and the horse manure and horse:hay:hops composts had high Mn (769 and 627 ppm, respectively) relative to the average value for all composts. With the exception of $\mathrm{Cu}$, micronutrient concentrations in bark:biosolids compost, which is not Organic Materials Review

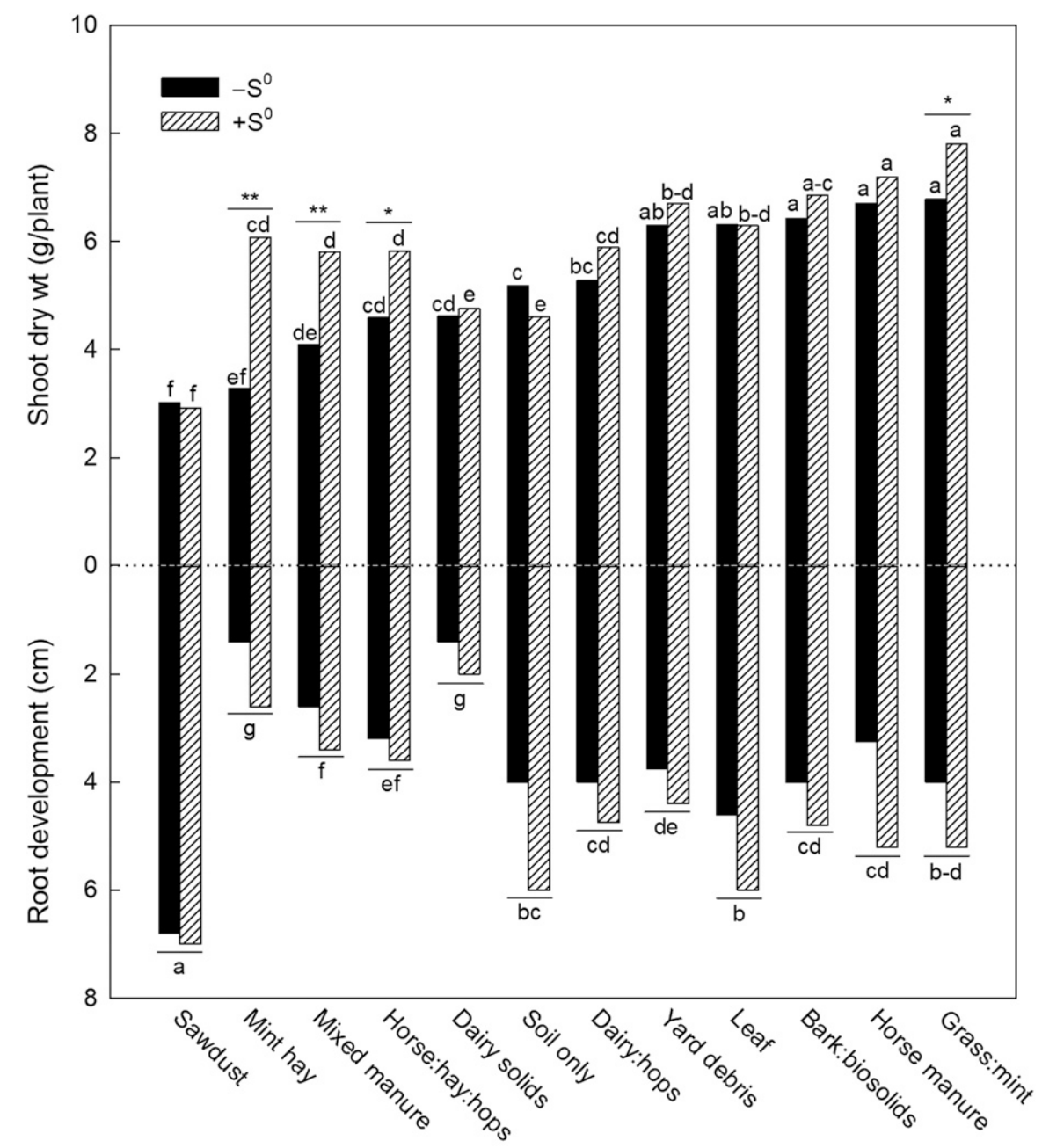

\section{Soil amendment}

Fig. 2. Shoot dry weight and root development of 'Duke' blueberry plants grown in soil amended with untreated $\left(-\mathrm{S}^{0}\right)$ or sulfur-acidified $\left(+\mathrm{S}^{0}\right)$ compost or douglas fir sawdust (industry standard), or in soil only. Bars are arranged according to rank of shoot dry weight in treatments without $S^{0}(n=5)$. Asterisks indicate shoot dry weight or root growth were affected by $\mathrm{S}^{0}$ acidification at $P \leq 0.05\left(^{*}\right)$ or $0.01\left(^{* *}\right)$. 
Institute-approved for organic production, were similar to that found in composts derived exclusively from agricultural feedstocks.

\section{Changes in compost chemistry accompanying acidification with elemental sulfur}

Compost acidification. Acidification with $\mathrm{S}^{0}$ reduced compost $\mathrm{pH}$ by an average of 1.9 units and increased compost EC by an average of $1.6 \mathrm{dS} \cdot \mathrm{m}^{-1}$ (Table 3 ). Once acidified, $\mathrm{pH}$ differed by as much as 2.7 units among the composts, which was expected given the differences in $\mathrm{pH}$ and $\mathrm{pH}$ buffering capacity before acidification. The total amount of $\mathrm{S}^{0}$ estimated to reduce compost $\mathrm{pH}$ to 5.0 averaged $30 \mathrm{~g} \cdot \mathrm{kg}^{-1}$ (Table 3). On a whole compost basis, this is equivalent to $6 \mathrm{~kg} \mathrm{~S}{ }^{0}$ per tonne of compost dry matter

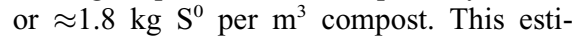
mate assumes that bulk density of the compost (dry weight basis) is $300 \mathrm{~kg} \cdot \mathrm{m}^{-3}$, and all of the $\mathrm{S}^{0}$ added to the compost is oxidized to $\mathrm{H}^{+}$. Costello and Sullivan (2014) reported that finely ground $\mathrm{S}^{0}$ was more than $85 \%$ effective at reducing $\mathrm{pH}$ (relative to $\mathrm{H}^{+}$from $\mathrm{H}_{2} \mathrm{SO}_{4}$ ) when it was incubated with moist composts for $28 \mathrm{~d}$. In an acid-base reaction, it takes $100 \mathrm{~g} \mathrm{CaCO}_{3}$ to neutralize the acidity from $32 \mathrm{~g} \mathrm{~S}^{0}$. Therefore, compost-supplied alkalinity (greater than $\mathrm{pH} \mathrm{5}$ ) in the present study was equivalent to $5.6 \mathrm{~kg} \mathrm{CaCO}_{3}$ per $\mathrm{m}^{3}$ compost.

The impact of compost $\mathrm{pH}$ buffering capacity on compost acidification is well illustrated by the comparison between dairy solids and mint hay compost (Table 3 ). Both of these composts had a pre-acidification $\mathrm{pH}$ value of 8.1. However, after acidification, $\mathrm{pH}$ dropped to 5.1 in mint hay compost and only 7.0 in dairy solids compost. Buffering capacity of dairy solids compost was about twice that of the mint hay compost. Across all composts, the calculated $\mathrm{S}^{0}$ requirement $\left(\mathrm{S}_{\text {req }}\right)$ was linearly related to the measured compost $\mathrm{pH}$ after reaction with $\mathrm{S}^{0}$ : [acidified compost $\mathrm{pH}$ (with uniform $\mathrm{S}^{0}$ rate $)=0.0049 * \mathrm{~S}_{\mathrm{req}}+3.88\left(r^{2}=0.74 ; P<\right.$ 0.001)].

Compost saturation extract. Sulfur addition increased soluble cations $\left(\mathrm{K}^{+}, \mathrm{Ca}^{2+}\right.$, and $\mathrm{Mg}^{2+}$ ) and $\mathrm{SO}_{4}{ }^{2-}$ present in saturation extracts (Table 3). Across composts, acidification increased cation concentration in saturation extracts from 22 to $36 \mathrm{mmol}^{(+)} / \mathrm{L}$ of $\mathrm{K}, 5$ to 19 $\mathrm{mmol}^{(+)} / \mathrm{L}$ of Ca, 5 to $20 \mathrm{mmol}^{(+)} / \mathrm{L}$ of $\mathrm{Mg}$, and 6 to $9 \mathrm{mmol}^{(+)} / \mathrm{L}$ of $\mathrm{Na}$, and increased total cation charge by an average of $44 \mathrm{mmol}^{(+)} / \mathrm{L}$. Acidification also increased total anion charge by $40 \mathrm{mmol}^{(-)} / \mathrm{L}$ and extractable $\mathrm{SO}_{4}-\mathrm{S}$ by 18 to $83 \mathrm{mmol}^{(-)} / \mathrm{L}$. This latter increase in $\mathrm{SO}_{4}-\mathrm{S}$ was expected because $\mathrm{SO}_{4}{ }^{2-}$ is the product of $\mathrm{S}^{0}$ oxidation. Soluble $\mathrm{N}$ in saturation extracts was low relative to $\mathrm{SO}_{4}-\mathrm{S}\left(<10 \mathrm{mmol}^{(+o r-)} / \mathrm{L}\right.$ of $\mathrm{NH}_{4}-\mathrm{N}$ and $\mathrm{NO}_{3}-\mathrm{N}$ ).

\section{Effects of untreated and acidified composts on soil $\mathbf{p H}$ and $\mathbf{E C}$}

Soil $\mathrm{pH}$. Compost increased soil $\mathrm{pH}$, on average, while $\mathrm{S}^{0}$ acidification of the composts reduced it (Table 4). Differences in soil $\mathrm{pH}$ in

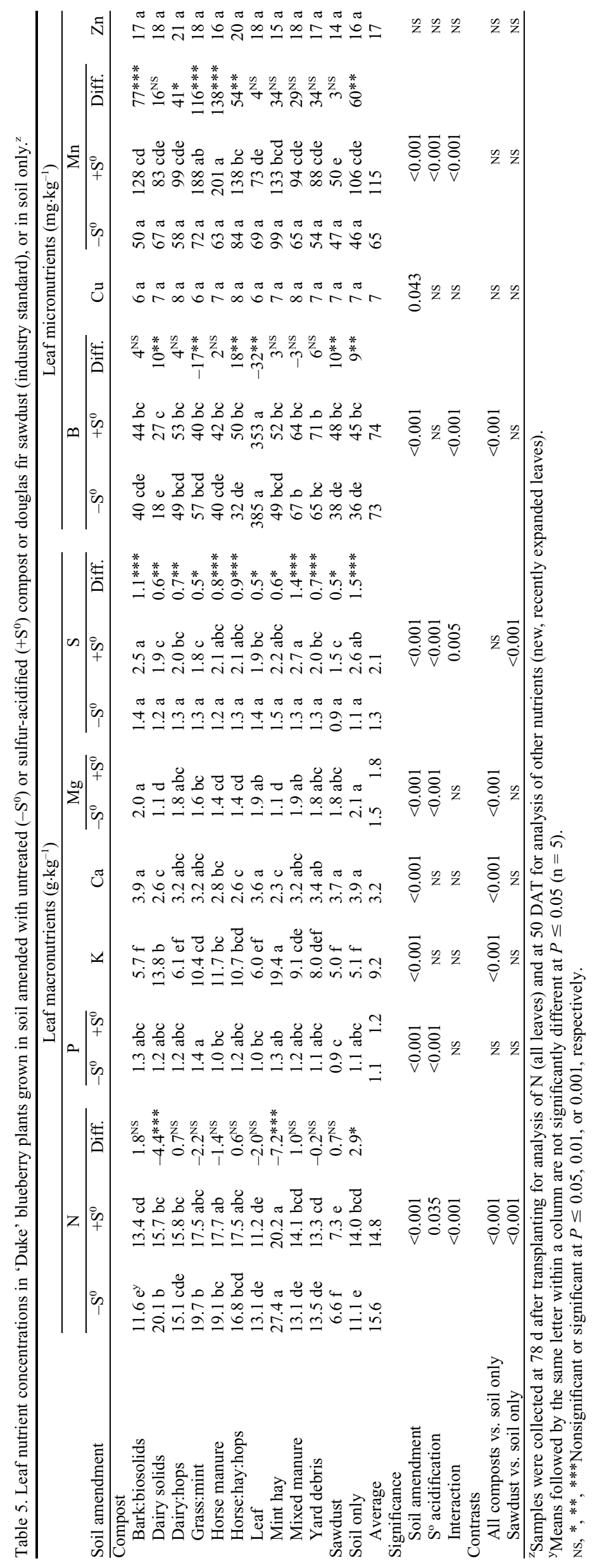

HortSCience Vol. 54(6) June 2019 
response to compost or $\mathrm{S}^{0}$ (Table 4) were associated with differences in compost $\mathrm{pH}$ and $\mathrm{pH}$ buffering capacity (Table 3 ). This was expected given that $S_{\text {req }}$ was calculated from $\mathrm{pH}$ and from the $\mathrm{pH}$ buffering capacity measured in the composts (Table 3; Eq. [1]). As a result, soil $\mathrm{pH}$ at the termination of the growth trial at 78 DAT was linearly related to $\mathrm{S}_{\text {req }}$ [with $\mathrm{S}^{0}$ addition, soil $\mathrm{pH}(78$ $\mathrm{DAT})=4.32+0.24 * \mathrm{~S}_{\text {req }}\left(r^{2}=0.64, P<0.05\right.$, $\mathrm{n}=10)$; and without $\mathrm{S}^{0}$ addition, soil $\mathrm{pH}(78$ $\mathrm{DAT})=5.07+0.21 * \mathrm{~S}_{\text {req }}\left(r^{2}=0.85, P<0.01\right.$, $\mathrm{n}=10)]$. With the exception of the dairy solids treatment, soil $\mathrm{pH}$ was also highly correlated to initial $\mathrm{pH}$ of the untreated and acidified composts (Fig. 1). Data points for dairy solids compost were excluded as outliers. Once these points were removed, soil $\mathrm{pH}$ increased by 0.3 units for every unit increase in compost $\mathrm{pH}$.

Leachate and soil EC. Compost and $\mathrm{S}^{0}$ acidification increased EC of the leachate collected during the greenhouse trial (Table 4). Leachate EC from the acidified treatments averaged twice that measured from those that were untreated. However, leachate EC did not respond uniformly to $\mathrm{S}^{0}$ across the composts. For example, increases in leachate EC as a result of $\mathrm{S}^{0}$ ranged from 0.7 to $3.2 \mathrm{dS} \cdot \mathrm{m}^{-1}$ among composts at $10 \mathrm{DAT}$. At that point in time, leachate EC was positively correlated to the initial EC of the compost $\left(r^{2}=0.89 ; P<\right.$ 0.001).

Blueberry is sensitive to excessive soluble salts $\left(\mathrm{EC}>2.0 \mathrm{dS} \cdot \mathrm{m}^{-1}\right)$ in soil solution (Machado and Bryla, 2014). However, plants in the present study grew better in acidified compost, even though EC of the compost was roughly doubled by acidification (Table 4). Two factors may have reduced damage from excessive soluble salts in this trial. First, when EC was high during the first days of the trial, evaporative demand was low because it was early spring and the plants at that point had limited leaf area. Second, the plants were well watered beyond container capacity ( $>20 \%$ drainage), which likely leached a large amount of salts from the pots. Whether $\mathrm{S}^{0}$ was added to the compost, EC declined over time to $\leq 1.5 \mathrm{dS} \cdot \mathrm{m}^{-1}$ in the leachate at 50 DAT and to $\leq 0.5 \mathrm{dS} \cdot \mathrm{m}^{-1}$ in the soil at 78 DAT (Table 4). Because issues with excessive mineral $\mathrm{N}, \mathrm{K}$, and other soluble salts will be greater when high rates of compost are applied immediately before planting, growers should consider applying compost a few months ahead of planting and, if necessary, leach the salts using sprinklers. In maritime climates such as western Oregon and Washington, precipitation typically exceeds $50 \mathrm{~cm}$ during the dormant season (October through March). Therefore, most of the soluble salt from a fall application of compost would be leached well below the root zone $(\approx 0.3 \mathrm{~m}$ deep; Bryla and Strik, 2007) by the following spring. Suitable composts for blueberry (i.e., those low in soluble salts, including $\mathrm{NO}_{3}-\mathrm{N}$ ) are unlikely to degrade groundwater quality via winter leaching (Sullivan et al., 2014).
Growth and nutrient status of blueberry plants grown in soil amended with acidified and nonacidified compost

Shoot dry weight and root development. Total shoot dry weight and root development were significantly affected by compost $(P<$ $0.001)$ and $\mathrm{S}^{0}$ acidification $(P<0.001)$. There was also an interaction between compost and $\mathrm{S}^{0}$ acidification on shoot dry weight $(P<0.001)$, indicating that plant response to $\mathrm{S}^{0}$ differed among the compost treatments.

Without $\mathrm{S}^{0}$ acidification, the best composts, in terms of their effect on total shoot dry weight, were horse manure and most of the composts produced primarily from plant-based feedstocks, including grass:mint, bark:biosolids, leaf, and yard debris (6.3$6.8 \mathrm{~g} /$ plant) (Fig. 2). Nonacidified mint hay compost and those made from dairy manure (i.e., dairy solids, dairy:hops, and mixed manure), on the other hand, resulted in lower total shoot dry weights among the treatments (3.3$5.3 \mathrm{~g} /$ plant) and, with the exception of dairy: hops, the least amount of root development $(1.4-3.4 \mathrm{~cm})$. These latter composts had high $\mathrm{pH}$ initially and, in some cases, a high amount of soluble salts (Table 3 ).

Acidification with $\mathrm{S}^{0}$ increased total shoot dry weight in mint (i.e., mint hay and grass: mint) or mixed horse manure (i.e., horse: hay:hops and mixed manure) composts but had no effect in soil only, sawdust, or other composts (Fig. 2). The use of $\mathrm{S}^{0}$ also improved root development by an average of $27 \%$ (Fig. 2). However, none of the treatments had more root development than plants grown in soil amended with sawdust. Whether $\mathrm{S}^{0}$ was added, roots of the plants in the sawdust treatment occupied nearly the entire volume of the pots by 78 DAT.

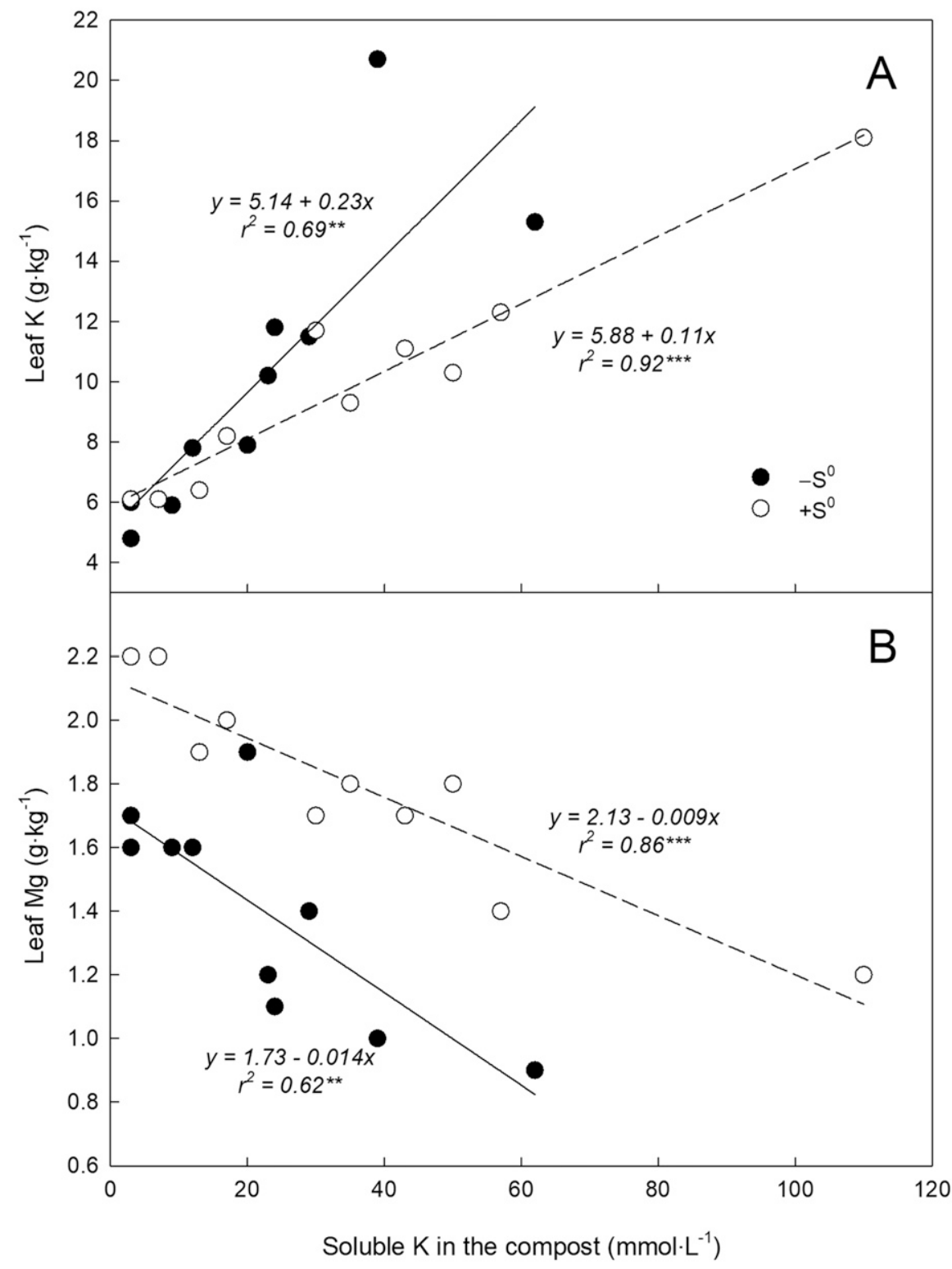

Fig. 3. Relationships between the concentration of $\mathrm{K}(\mathbf{A})$ and $\mathrm{Mg}(\mathbf{B})$ in the leaves of 'Duke' blueberry and soluble $\mathrm{K}$ in the compost. Composts were untreated $\left(-\mathrm{S}^{0}\right)$ or acidified $\left(+\mathrm{S}^{0}\right)$ by adding $32 \mathrm{~g}$ of elemental $\mathrm{S}$ per kg compost-C. Each regression was significant at $P<0.01$ (**) or 0.001 (***). 
Leaf nutrient analysis. The concentration of nutrients in the leaves responded to compost and $\mathrm{S}^{0}$ acidification (Table 5). In many cases, compost increased the concentration of $\mathrm{N}, \mathrm{K}$, and/or B in the leaves, relative to soil only, and reduced the concentration of $\mathrm{Ca}$ and $\mathrm{Mg}$. Acidification, on the other hand, reduced leaf $\mathrm{N}$ in two compost treatments (dairy solids and mint hay) and increased the concentration of $\mathrm{P}, \mathrm{Mg}$, and $\mathrm{S}$ in the leaves by an average of $0.1,0.3$, and $0.8 \mathrm{~g} \cdot \mathrm{kg}^{-1}$, respectively. Furthermore, it had mixed effects on B in the leaves and about doubled or tripled the concentration of $\mathrm{Mn}$ in the leaves when plants were grown with bark:biosolids, dairy:hops, grass:mint, horse manure, or horse:hay:hops compost, or in soil only.

Leaf $\mathrm{N}$ was linearly correlated to total $\mathrm{N}$ in the composts [leaf $\mathrm{N}\left(\mathrm{g} \cdot \mathrm{kg}^{-1}\right)=11.05+$ $0.347^{*}$ compost total $\mathrm{N}\left(\mathrm{g} \cdot \mathrm{kg}^{-1}\right)\left(r^{2}=0.69 ; P<\right.$ $0.01)]$ and was lowest when soil was amended with sawdust. Sawdust immobilizes soil N (Allison, 1965) and was the only treatment with obvious symptoms of $\mathrm{N}$ deficiency (chlorotic leaves with small, reddish, necrotic spots; Polashock et al., 2017). To avoid induced $\mathrm{N}$ deficiency, Bollen and Lu (1957) recommended applying 2.5 to $5.0 \mathrm{~kg}$ of $\mathrm{N}$ for each tonne of douglas fir sawdust incorporated into soil. Additional $\mathrm{N}$ fertilization is needed when sawdust is used as a mulch (Hart et al., 2006). Results of the present study suggest that compost incorporation into soil will reduce or eliminate the need for additional $\mathrm{N}$ fertilization when soil is mulched with sawdust.

Leaf $\mathrm{K}$ also increased linearly with increasing amounts of soluble $\mathrm{K}$ in the compost (Fig. 3A). In this case, the slope of the relationship was reduced by compost acidification. Increased leaf dry matter in plants grown with acidified compost likely diluted leaf $\mathrm{K}$. Leaf $\mathrm{Mg}$, in contrast, decreased as compost $\mathrm{K}$ and leaf $\mathrm{K}$ increased (Fig. 3B). Leaf $\mathrm{Ca}$ concentration also decreased with compost soluble $\mathrm{K}$ : Leaf $\mathrm{Ca}=-0.013 *$ Compost soluble $\mathrm{K}+3.0\left(r^{2}=0.36, P<0.001\right)$. Magnesium deficiency may have played a role in declining root growth and shoot dry matter with increasing $\mathrm{K}$ inputs from compost. Competition between $\mathrm{K}^{+}$and $\mathrm{Mg}^{2+}$ has been reported to result in $\mathrm{Mg}$ deficiency in many plants (Dibb and Thompson 1985), including tree fruit and small fruit crops (Cummings 1985). However, this issue was not evident in a long-term field trial on organic northern highbush blueberry in Oregon (Sullivan et al., 2015). In this case, applying a 6-cm-deep layer of yard debris compost as mulch $(4 \mathrm{~cm}$ at planting plus $2 \mathrm{~cm}$ at 4 years after planting) increased exchangeable soil K (0-20 cm depth) from 250 to $400 \mathrm{~g} \cdot \mathrm{kg}^{-1} \mathrm{~K}$ but had no effect on concentration of $\mathrm{K}\left(5.2 \mathrm{~g} \cdot \mathrm{kg}^{-1}\right), \mathrm{Ca}$ $\left(4.5 \mathrm{~g} \cdot \mathrm{kg}^{-1}\right)$, or $\mathrm{Mg}\left(1.5 \mathrm{~g} \cdot \mathrm{kg}^{-1}\right)$ in recently expanded leaves of the plants. Forge et al. (2013), in contrast, conducted a similar study on northern highbush blueberry in British Columbia, Canada, and reported that the concentration of $\mathrm{K}$ in the leaves increased from $5 \mathrm{~g} \cdot \mathrm{kg}^{-1}$ with sawdust mulch to $8 \mathrm{~g} \cdot \mathrm{kg}^{-1}$ with a 7- to $10-\mathrm{cm}$-deep layer of yard debris compost mulch, while the concentration of $\mathrm{Mg}$ in the leaves declined from $1.4 \mathrm{~g} \cdot \mathrm{kg}^{-1}$ to $1.1 \mathrm{~g} \cdot \mathrm{kg}^{-1}$, respectively. Hart et al. (2006) recommend a concentration of 4 to $7 \mathrm{~g} \cdot \mathrm{kg}^{-1} \mathrm{~K}$ for the region, and 1.3 to $2.5 \mathrm{~g} \cdot \mathrm{kg}^{-1} \mathrm{Mg}$. Therefore, this latter study by Forge et al. (2013) raises concerns that high $\mathrm{K}$ in compost may result in $\mathrm{Mg}$ deficiency in northern highbush blueberry. In the present trial, acidification of compost or soil alone increased leaf $\mathrm{Mg}$ by an average of $0.3 \mathrm{~g} \cdot \mathrm{kg}^{-1}$ (Table 5). Therefore, compost acidification may be an effective means of reducing $\mathrm{K}$-induced $\mathrm{Mg}$ deficiency when plants are grown with compost.

With respect to micronutrients, plants grown with leaf compost had high concentrations of B in the leaves (350-380 mg. $\left.\mathrm{kg}^{-1}\right)$. The current recommendation for northern highbush blueberry is only 31 to $80 \mathrm{mg} \cdot \mathrm{kg}^{-1}$ $\mathrm{B}$, and leaf $\mathrm{B}>150 \mathrm{mg} \cdot \mathrm{kg}^{-1}$ is considered an indicator of possible toxicity (Hart et al., 2006). The deciduous tree leaves that were used as feedstock for the leaf compost were obtained from municipal street sweeping. Heckman and Kluchinski (1996) found that leaves collected from streets had higher levels of $\mathrm{B}$ than those collected directly from trees. Thus, a likely source of B in our leaf compost is grit and dust recovered from the surface of the street along with the leaves.

Solubility of metal micronutrients such as $\mathrm{Cu}, \mathrm{Mn}$, and $\mathrm{Zn}$ often increase with acidification in soil or organic media as well as with addition of organic matter (Handreck and Black, 2010; Havlin et al., 2014). However, neither leaf $\mathrm{Cu}$ nor $\mathrm{Zn}$ were strongly affected by compost or $\mathrm{S}^{0}$ acidification in the present study. Leaf $\mathrm{Mn}$, on the other hand, increased with $\mathrm{S}^{0}$ in several compost treatments, as mentioned, and in two instances was higher with acidified compost (grass:mint and horse manure) than with acidified soil only. In each case, leaf Mn was well below those associated with Mn toxicity in blueberry ( $>400 \mathrm{mg} \cdot \mathrm{kg}^{-1}$; Bañados et al., 2008). Leaf Mn is often high in blueberry due to the acidic growing conditions (Retamales and Hancock, 2012).

\section{Relationships between key chemical compost traits and plant growth and mineral nutrition of northern highbush blueberry}

One of the primary goals of this research was to identify composts that can be used to supply $\mathrm{N}$ to blueberry without causing damage from excessive nutrients or high $\mathrm{pH}$. However, as compost $\mathrm{N}$ increased in the present study, so did compost EC, compost total $\mathrm{K}$, and compost soluble $\mathrm{K}$ in both untreated and acidified composts (Table 6). We did not find any composts that supplied high concentrations of total $\mathrm{N}$ without accompanying

Table 6. Spearman rank order correlations of key chemical compost traits, total shoot dry weight, and root growth determined for 10 untreated or sulfur-acidified composts used as soil amendments in pots of 'Duke' blueberry. ${ }^{z}$

\begin{tabular}{|c|c|c|c|c|c|c|}
\hline Trait & Compost total $\mathrm{N}$ & Compost $\mathrm{pH}$ & Compost EC & Compost total $\mathrm{K}$ & Compost soluble $\mathrm{K}$ & Total shoot dry w \\
\hline \multicolumn{7}{|l|}{ Untreated composts } \\
\hline Compost EC & $0.841 * * *$ & 0.424 & & & & \\
\hline Compost total $\mathrm{K}$ & $0.774 * *$ & $0.747 *$ & $0.866^{* * *}$ & & & \\
\hline Total shoot dry wt & -0.347 & $-0.905 * * *$ & -0.364 & $-0.670^{*}$ & -0.266 & \\
\hline Root growth & $-0.619^{*}$ & $-0.741 *$ & $-0.784 * *$ & $-0.895 * * *$ & $-0.753 * *$ & $0.709 *$ \\
\hline \multicolumn{7}{|l|}{ Acidified composts } \\
\hline Compost total $\mathrm{K}$ & $0.774 * *$ & 0.429 & $0.912 * * *$ & & & \\
\hline Compost soluble $\mathrm{K}$ & $0.750^{*}$ & 0.391 & $0.927 * * *$ & $0.997 * * *$ & & \\
\hline Total shoot dry wt & -0.113 & $-0.782 * *$ & -0.407 & -0.512 & -0.498 & \\
\hline Root growth & $-0.627^{*}$ & $-0.684^{*}$ & $-0.711^{*}$ & $-0.790 * *$ & $-0.766^{* *}$ & $0.762 * *$ \\
\hline \multicolumn{7}{|l|}{ Pooled } \\
\hline Compost $\mathrm{pH}$ & 0.158 & & & & & \\
\hline Compost EC & $0.736 * * *$ & -0.124 & & & & \\
\hline
\end{tabular}

$\mathrm{EC}=$ electrical conductivity.

${ }^{\mathrm{z}}$ Untreated and acidified composts were analyzed separately $(\mathrm{n}=10)$ and pooled $(\mathrm{n}=20)$.

$*, * *, * *$ Significant at $P \leq 0.05,0.01$, or 0.001 , respectively. 
negative compost analysis characteristics. Total $\mathrm{N}$ in compost was not well correlated with compost $\mathrm{pH}$.

Across composts (acidified and nonacidified), total shoot dry weight was negatively correlated to compost $\mathrm{pH}$ and total $\mathrm{K}$ but was not correlated to total $\mathrm{N}, \mathrm{EC}$, or soluble $\mathrm{K}$ (Table 6). Shoot dry weight increased linearly as compost $\mathrm{pH}$ declined from 7.6 to 4.3 and dropped sharply when compost $\mathrm{pH}$ exceeded 7.6 (Fig. 4A). At pH 8, total dry weight of the plants was $\approx 50 \%$ of that produced by a compost with a $\mathrm{pH}$ of 5 . Each
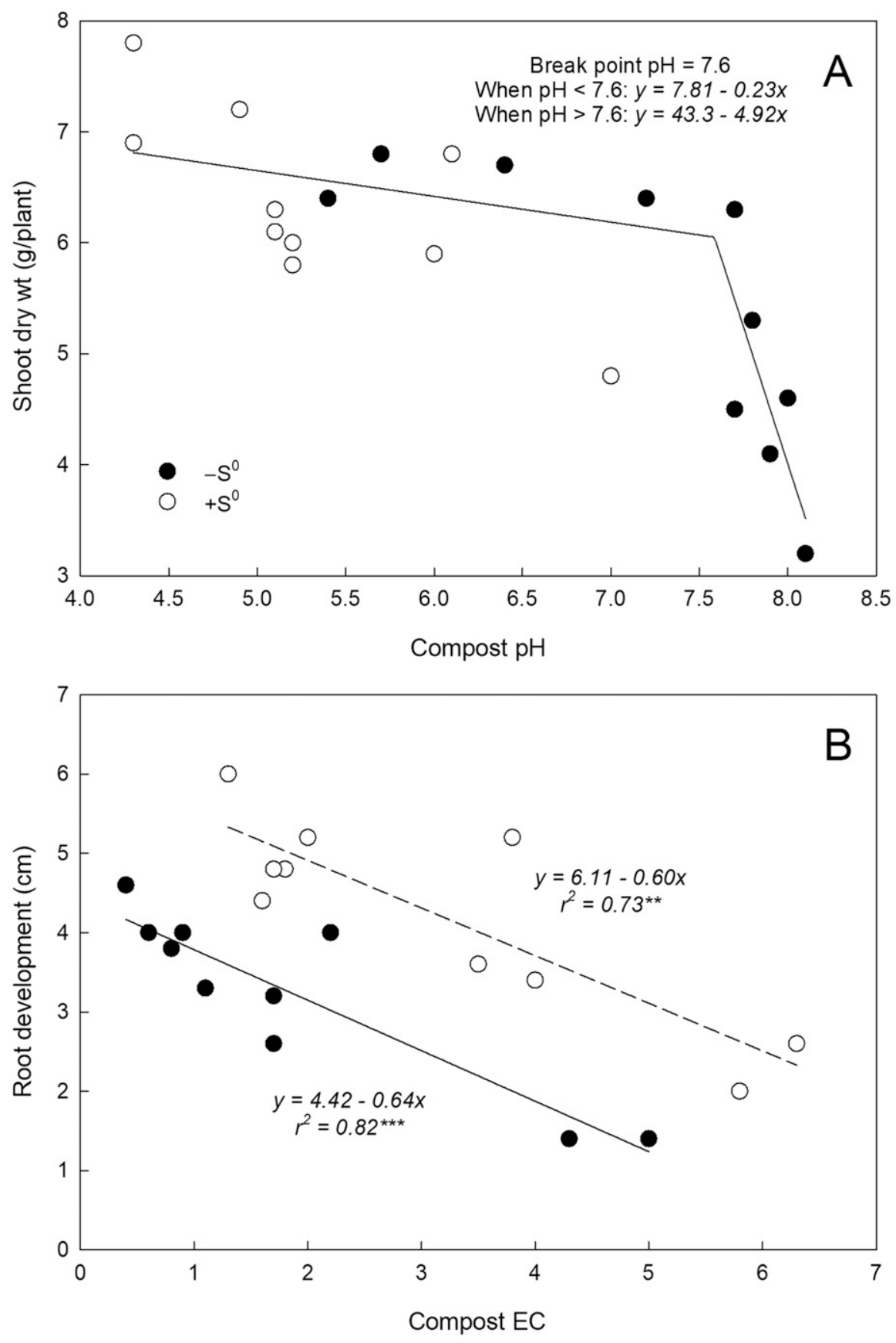

Fig. 4. Relationships between shoot dry weight and compost $\mathrm{pH}$ (A) and between root development and compost electrical conductivity (EC) (B) in 'Duke' blueberry. The plants were grown in soil amended with untreated $\left(-\mathrm{S}^{0}\right)$ or sulfur-acidified $\left(+\mathrm{S}^{0}\right)$ compost. Data in panel $\mathbf{A}$ were fit using piecewise, two segment linear regression $\left(r^{2}=0.76, P<0.001\right)$; a breakpoint was found at $\mathrm{pH} 7.6$. Regressions in panel B were significant at $P<0.01(* *)$ or $0.001(* * *)$. linearly with increasing compost EC, and the slope of the regression was similar between acidified and nonacidified composts (Fig. 4B). However, root growth was superior overall in the acidified composts, even though acidification practically doubled compost EC, on average, and nearly tripled EC of the leachate collected from the pots at 10 DAT (Tables 3 and 4). The observed decline in root growth with compost EC was confounded by covariance of other nutrients present in the compost. For example, compost EC was highly correlated with total $\mathrm{K}$ and soluble $\mathrm{K}$ in the compost (Table 6). Furthermore, the effect of compost acidification on $\mathrm{pH}$ was more persistent than its effect on EC. High EC levels from compost were present in soil during the first $10 \mathrm{~d}$ of the growth trial but declined thereafter as salts were presumably leached from the pots by irrigation and drainage (Table 4). Because $\mathrm{K}$ is less attracted to cation-exchange sites in soil and compost than $\mathrm{Ca}$ or $\mathrm{Mg}$, it is likely that $\mathrm{K}$ was the cation present in the highest concentration in leachate at 10 and 50 DAT in this trial.

Total $\mathrm{K}$ analysis of compost is likely a better indicator of the salt hazard of compost than extractable K or compost EC. Few laboratories provide saturated extract $\mathrm{K}$ analysis, and because a qualitative judgment has to be made about when the compost is "saturated" and ready for vacuum extraction, the saturation procedure is less reproducible than analysis of total $\mathrm{K}$. Total $\mathrm{K}$ analysis is also a more universally reproducible method than is the measurement of compost EC. Compost EC will vary considerably depending on the amount of water added to the sample before analysis. Costello and Sullivan (2014) reported that compost EC determined in saturation extract was two to four times greater than EC measured in 1:10 compost to water ratio. Many commercial laboratories testing compost routinely use a 1:5 compost-to-water ratio (Thompson et al., 2001), but this method is not suitable for composts that have high water holding capacity or when $\mathrm{pH}$ is determined using larger diameter probes.

\section{Conclusions}

This research was designed as a screening study to evaluate the suitability of diverse composts for northern highbush blueberry and to determine chemical characteristics of composts that are associated with positive plant growth response. We found that aboveground growth of the plants was best when compost $\mathrm{pH}$ was $<7.0$, and both shoot and root growth were improved consistently when the composts were acidified with $\mathrm{S}^{0}$. Among the most favorable composts for blueberry was grass:mint, horse manure, bark:biosolids, leaf, and yard debris compost. Availability of most of these composts may be limited in many regions. However, yard debris composts are widely available from commercial vendors, and their chemical characteristics are suitable for building soil organic matter without supplying excessive mineral $\mathrm{N}$ and 
excessive soluble salts. Sullivan et al. (2014) reported that, on average, yard debris compost obtained from commercial suppliers in Oregon had a $\mathrm{pH}$ of 7 , an EC of $4 \mathrm{dS} \cdot \mathrm{m}^{-1}$ (saturation extract), a $\mathrm{C}: \mathrm{N}$ ratio of 21 , and contained $560 \mathrm{~g} \cdot \mathrm{kg}^{-1}$ organic matter, $13 \mathrm{~g} \cdot \mathrm{kg}^{-1}$ total $\mathrm{N}$, and $8,17,4$, and $1 \mathrm{~g} \cdot \mathrm{kg}^{-1}$ of total $\mathrm{K}$, $\mathrm{Ca}, \mathrm{Mg}$, and $\mathrm{Na}$, respectively. The main concern with yard debris compost is that it supplies more K than needed by blueberry, which may become a problem if it is reapplied frequently to the same field. We recognize that this was a short-term study conducted in pots with small blueberry plants and therefore is only capable of providing a preliminary assessment of the composts. Further evaluation will be needed on a field basis to confirm our findings.

\section{Literature Cited}

Allison, F.E. 1965. Decomposition of wood and bark sawdusts in soil, nitrogen requirements, and effects on plants. U.S. Dept. Agr. Tech. Bull. No. 1332.

Anderson, J.P.E. 1982. Soil respiration (Method 41-3.2). Methods of soil analysis. Chemical and microbiological properties. Agronomy Monograph 9 (Part 2). Amer. Soc. Agron. Soil Sci. Soc. Amer., Madison, WI.

Bañados, M.P., F. Ibáñez, and A.M. Toso. 2008. Manganese toxicity induces abnormal shoot growth in 'O'Neal' blueberry. Acta Hort. 810:509-512.

Bary, A.I., D.M. Sullivan, and C.G. Cogger. 2016. Fertilizing with manure and other organic amendments. Pacific Northwest Ext. Publ. PNW533.

Bates, D.M. and D.G. Watts. 1988. Nonlinear regression analysis and its applications. Wiley, New York.

Bollen, W.B. and K.C. Lu. 1957. Effect of douglasfir sawdust mulches and incorporations on soil microbial activities and plant growth. Soil Sci. Soc. Proc. 21:35-41.

Bryla, D.R. and B.C. Strik. 2007. Effects of cultivar and plant spacing on the seasonal water requirements of highbush blueberry. J. Amer. Soc. Hort. Sci. 132:270-277.

Carrión, C., R. Garcia de la Fuente, F. Fomes, R. Puchades, and M. Abad. 2008. Acidifying composts from vegetable crop wastes to prepare growing media for containerized crops. Compost Sci. Util. 16:20-29.

Clark, J. 1991. Rabbiteye and southern highbush blueberry response to sawdust mulch. Ark. Farm Res. Jan.-Feb:3.

Clark, J.R. and J.N. Moore. 1991. Southern highbush blueberry response to mulch. HortTechnology $1: 52-54$.

Costello, R.C. and D.M. Sullivan. 2014. Determining the $\mathrm{pH}$ buffering capacity of compost via titration with dilute sulfuric acid. Waste Biomass Valoriz. 5:505-513.

Cummings, G.A. 1985. Potassium nutrition of deciduous and small fruits, p. 1087-1104. In: R. Munson (ed.). Potassium in agriculture. Soil Science Society of America, Madison, WI.

Dibb, D.W. and W.R. Thompson, Jr. 1985. Interaction of potassium with other nutrients, $p$. 522-524. In: R. Munson (ed.). Potassium in agriculture. Soil Sci. Soc. Amer., Madison, WI.

Eck, P. 1988. Blueberry science. Rutgers Univ. Press, London.
Forge, T.A., W. Temple, and A.A. Bomke. 2013. Using compost as mulch for highbush blueberry. Acta Hort. 1001:369-376.

García de la Fuente, R., C. Carrión, S. Botella, F. Fornes, V. Noguera, and M. Abad. 2007. Biological oxidation of elemental sulphur added to three composts from different feedstocks to reduce their $\mathrm{pH}$ for horticultural purposes. Bioresour. Technol. 98:3561-3569.

Gavlak, R.G., D.A. Horneck, and R.O. Miller 2005. Soil, plant and water reference methods for the western region. 3rd ed. Western Region Extension Report (WREP-125). WERA-103 Technical Committee. 8 Mar. 2017. <http:// www.naptprogram.org/files/napt/western-statesmethod-manual-2005.pdf $>$.

Germida, J.J. and H.H. Janzen. 1993. Factors affecting the oxidation of elemental sulfur in soils. Nutr. Cycl. Agroecosyst. 35:101-114.

Gough, R.E. 1994. The highbush blueberry and its management, p. 36-41. Food Products Press, New York.

Handreck, K. and N. Black. 2010. Growing media for ornamental plants and turf. 4th ed. Univ. New South Wales Press, Sydney.

Hart, J., B. Strik, L. White, and W. Yang. 2006. Nutrient management for blueberries in Oregon. Ore. St. Univ. Ext. Serv. EM8918.

Havlin, J.L., S.L. Tisdale, W.L. Nelson, and J.D. Beaton. 2014. Soil fertility and fertilizers. An introduction to nutrient management. 8th ed. Pearson Inc., Upper Saddle River, NJ.

Haynes, R.J. and R.S. Swift. 1986. Effect of soil amendments and sawdust mulching on growth, yield and leaf nutrient content of highbush blueberry plants. Scientia Hort. 29:229-238.

He, Z., X. Yang, B.A. Kahn, P.J. Stoffella, and D.V. Calvert. 2001. Plant nutrition benefits of phosphorus, potassium, calcium, magnesium, and micronutrients from compost utilization, $\mathrm{p}$. 95-120. In: P.J. Stofella and B.A. Kahn (eds.). Compost utilization in horticultural cropping systems. CRC Press, Boca Raton, FL.

Heckman, J.R. and D. Kluchinski. 1996. Chemical composition of municipal leaf waste and hand collected urban leaf litter. J. Environ. Qual. 25:355-362.

Julian, J.W., B.C. Strik, H.O. Larco, D.R. Bryla, and D.M. Sullivan. 2012. Costs of establishing organic northern highbush blueberry: Impacts of planting method, fertilization, and mulch type. HortScience 47:866-873.

Krewer, G. and J. Ruter. 2012. Fertilizing highbush blueberries in pine bark beds. Univ. Georgia Coop. Ext. Bul. 1291.

Lareau, M. 1989. Growth and productivity of highbush blueberries as affected by soil amendments, nitrogen fertilization and irrigation. Acta Hort. 241:126-131.

Machado, R.M.A., D.R. Bryla, and O. Vargas. 2014. Effects of salinity induced by ammonium sulfate fertilizer on root and shoot growth of highbush blueberry. Acta Hort. 1017:407-414.

Moore, J.N. 1979. Highbush blueberry culture in the upper South. 4th Natl. Blueberry Res. Workers Conf. 4:84-86.

Polashock J.J., F.L. Caruso A.L. Averill, and A.C. Schilder. 2017. Compendium of blueberry, cranberry, and lingonberry diseases and pests. 2nd ed. APS Press, St. Paul, MN.

Retamales, J.B. and J.E. Hancock. 2012. Blueberries. Crop production science in horticulture series. CABI International, Wallingford, UK.

Sikora, L.J. and R.A.K. Szmidt. 2001. Nitrogen sources, mineralization rates, and nitrogen nutrition benefits to plants from composts, p. 95120. In: P.J. Stofella and B.A. Kahn (eds.). Compost utilization in horticultural cropping systems. CRC Press, Boca Raton, FL.

Stevenson, F.J. 1994. Electrochemical and ionexchange properties of humic substances, p. 350 377. In: J.F. Stevenson (ed.). Humus chemistry: Genesis, composition, reactions. John Wiley and Sons, New York.

Strik, B.C., C.E. Finn, and P.P. Moore. 2014. Blueberry cultivars for the Pacific Northwest. Pacific Northwest Ext. Publ. PNW656.

Strik, B.C., A. Vance, and D.R. Bryla. 2016. Organic production systems research in blueberry and blackberry - a review of industry driven studies. Acta Hort. 1117:139-148.

Strik, B.C., A. Vance, D.R. Bryla, and D.M. Sullivan. 2017. Organic production systems in northern highbush blueberry: I. impact of planting method, cultivar, fertilizer, and mulch on yield and fruit quality from planting through maturity. HortScience 52:1201-1213.

Strik, B. and D. Yarborough. 2005. Blueberry production trends in North America, 1992 to 2003 and predictions for growth. HortTechnology 15:391-398.

Sullivan, D.M., A.I. Bary, T.J. Nartea, E.A. Myrhe, C.G. Cogger, and S.C. Fransen. 2003. Nitrogen availability seven years after a high-rate food waste compost application. Compost Sci. Util. 11:265-275.

Sullivan, D.M. and N. Bell. 2015. Preplant compost application improves landscape plant establishment and sequesters carbon in compacted soil. Proc. RAMIRAN 2015-16th International Conference Rural-Urban Symbiosis, Hamburg, Germany, 8-10 Sept. 2015. Paper \# TB-O_02.

Sullivan, D.M., D.R. Bryla, and R.C. Costello. 2014. Chemical characteristics of custom compost for highbush blueberry, p. 293-311. In: Z. He and H. Zhang (eds.). Applied manure and nutrient chemistry for sustainable agriculture and environment. Springer-Verlag, New York.

Sullivan, D.M. and R.O. Miller. 2001. Compost quality attributes, measurements and variability, p. 95-120. In: P.J. Stofella and B.A. Kahn (eds.). Compost utilization in horticultural cropping systems. CRC Press, Boca Raton, FL.

Sullivan, D.M., B.C. Strik, and D.R. Bryla. 2015. Evaluation of alternative mulches for blueberry over five production seasons. Acta Hort. 1076:171-178.

Thompson W.H., P. Leege P. Millner, and M. Watson. 2001. Test methods for the examination of composting and compost (TMECC). U.S. Composting Council, Ronkonkoma, NY.

U.S. Department of Agriculture National Resources Conservation Service. Willamette Soil Series. 2006. Web Site for Official Soil Series Descriptions and Series Classification. <https:// soilseries.sc.egov.usda.gov>.

Warncke, D.D. 1986. Analyzing greenhouse growth media by the saturation extract method. HortScience 21:223-225.

White, L.D. 2006. The effect of pre-plant incorporation with sawdust, sawdust mulch, and nitrogen fertilizer rate on soil properties and nitrogen uptake and growth of 'Elliott' highbush blueberry. Ore. State Univ., Corvallis, MS Thesis.

Wong, M.T.F., S. Nortcliff, and R.S. Swift. 1998. Method for determining the acid ameliorating capacity of plant residue compost, urban waste compost, farmyard manure, and peat applied to tropical soils. Commun. Soil Sci. Plant Anal. 29:2927-2937. 